\title{
Sarcopenia: prevalence and associated factors among elderly from a Brazilian capital
}

\author{
Sarcopenia: prevalência e fatores associados \\ em idosos de uma capital brasileira
}

Sarcopenia: prevalencia y los factores asociados

en ancianos en una capital brasileña

Andreia Pelegrini ${ }^{[a]}$, Giovana Zaperllon Mazo ${ }^{[a]}$, André de Araújo Pinto ${ }^{[a]}$, Tânia Rosane Bertoldo Benedetti ${ }^{[b]}$, Diego Augusto Santos Silva ${ }^{[b]}$, Edio Luiz Petroski ${ }^{[b]^{*}}$

[a] Universidade do Estado de Santa Catarina (UDESC), Florianópolis, SC, Brazil

[b] Universidade Federal de Santa Catarina (UFSC), Florianópolis, SC, Brazil

\begin{abstract}
Introduction: Sarcopenia has been currently considered a public health problem, affecting a large portion of the elderly and making them more susceptible to the risk of falls. Objective: To estimate the prevalence and factors associated with sarcopenia in the elderly from a Brazilian capital. Methods: This is an epidemiological study with cross-sectional design involving data of 439 elderly people from Florianópolis city, Santa Catarina
\end{abstract}

\footnotetext{
*AP: PhD, e-mail: andreia.pelegrini@udesc.br GZM: PhD, e-mail: giovana.mazo@udesc.br AAP: Doctoral student, e-mail: andregepecine@gmail.com TRBB: PhD, e-mail : tania.benedetti@ufsc.br DASS: PhD, e-mail : diego.augusto@ufsc.br ELP: PhD, e-mail: petroski@cds.ufsc.br
} 
state. The factors potentially associated with sarcopenia (sex, age, weight status) were tested using binary logistic regression, estimating the Odds Ratio and the respective confidence intervals. Results: The prevalence of sarcopenia was 33.3\% (95\% CI: 28.9, 36.9). Older women (75 years or more) showed less muscle mass in relation to other age groups $(\mathrm{p}<0.05)$. Elderly men, individuals that are 75 years or more, and those with low weight were the subgroups at higher risk for sarcopenia. Obese individuals were less likely to have the outcome. Conclusion: More than one-third of elderly people were diagnosed with sarcopenia. Men, individuals who are older, and those with low weight had a higher risk of having sarcopenia.

Keywords: Aging. Body Composition. Prevalence. Public Health. Sarcopenia.

\section{Resumo}

Introdução: A sarcopenia tem sido considerada atualmente um problema de saúde pública e afeta uma grande parcela dos idosos, deixando-os mais suscetíveis ao risco de quedas. Objetivo: Estimar a prevalência e os fatores associados à sarcopenia em idosos de uma capital brasileira. Métodos: Este é um estudo epidemiológico com delineamento transversal envolvendo dados de 439 idosos da cidade de Florianópolis, Santa Catarina. Os possíveis fatores associados à sarcopenia (sexo, idade, status do peso) foram testados por meio de regressão logística binária, estimando-se a Odds Ratio e os respectivos intervalos de confiança. Resultados: A prevalência de sarcopenia foi de $33,3 \%$. As mulheres com mais idade ( 75 anos ou mais) apresentaram menos massa muscular em relação às outras faixas etárias. Homens idosos, aqueles com 75 anos ou mais e os com baixo peso foram os subgrupos em maior risco de apresentar sarcopenia. Os obesos estiveram menos propensos a apresentar o desfecho. Conclusão: Mais de um terço dos idosos foram diagnosticados com sarcopenia. Os homens, aqueles idosos mais velhos e os com baixo peso tiveram maior risco de terem sarcopenia.

Palavras-chave: Envelhecimento. Composição Corporal. Prevalência. Saúde Pública. Sarcopenia.

\section{Resumen}

Introducción: La sarcopenia se ha considerado actualmente como un problema de salud pública y afecta a una gran parte de los ancianos, lo que los vuelve más vulnerables al riesgo de caídas. Objetivo: Estimar la prevalencia y los factores asociados a la sarcopenia en ancianos en una capital brasileña. Métodos: Este es un estudio epidemiológico con diseño transversal que involucra datos de 439 ancianos en la ciudad de Florianópolis, Santa Catarina. Los posibles factores asociados a la sarcopenia (sexo, edad, estado del peso) se probaron por medio de regresión logística binaria, estimándose el Odds Ratio y sus intervalos de confianza. Resultados: La prevalencia de sarcopenia fue del 33,3\%. Las mujeres de más edad (75 años o más) mostraron menor masa muscular en relación a otros grupos de edad. Los hombres, los ancianos con 75 años o más y aquellos con bajo peso fueron los subgrupos de mayor riesgo de sarcopenia. Los obesos eran menos propensos a presentar el desenlace. Conclusión: Se diagnosticó más de un tercio de los ancianos con sarcopenia. Los hombres, los ancianos mayores y con bajo peso tuvieron un riesgo mayor de tener sarcopenia.

Palabras clave: Envejecimiento. Composición Corporal. Prevalencia. Salud Pública. Sarcopenia.

\section{Introduction}

The population aging is a global phenomenon. According to the 2010 census data in Brazil, there was a reduction in the number of childrenandadolescentsaged up to 20yearsoldand anincrease in adultpopulation. Theelderly population in 2013 was 23.1 million and the life expectancy atbirth, 73.9years. Itis estimated that, in 2060, thenumberwill beapproximately 73.0 million of elderly people and that the life expectancy reaches 81.3 years [1]. These estimates have caused concern in public 
health authorities by virtue of the decline in physiological systems of people aged over 60 years [2], mainly concerning increased fat mass and reduced lean body mass, which are related to the impairment and/or functional dependence of the elderly [3]. This has been associated with an increased risk of falls, which in turn can result in debilitating lesions, physical disability and early mortality [4].

In this context, sarcopenia is considered as a worrying disease that can affect the public health in Brazil, since a large increase in the number of elderly people is expected in the near future. Sarcopenia is characterized by involuntary loss of lean mass and muscle strength associated with age. It has received growing attention in recent years and it is considered a disease that can be diagnosed and treated [4]. Nevertheless, associated with aging, this is a slow, progressive and apparently inevitable process; even between those individuals who exercise regularly [5] the symptoms appear to be highly prevalent $[2,6]$. A previous study showed a reduction in muscle mass after 40 years of approximately $5 \%$ per decade of life, and after 65 years of age, the problem became more pronounced, especially in lower limbs [7]. Also, it was observed considerable loss of muscle mass from the fifth decade of life in healthy physically active individuals in many countries $[8,9]$ and an estimate prevalence of sarcopenia of $17.8 \%$ in women with 60 years or older living in the urban area of a city from Brazil [10].

The estimation of muscle mass can be performed using differentevaluation methods, chief among which are the dualenergy X-ray absorptiometry (DEXA), magnetic resonance imaging, and computed tomography [8]. Despite the high cost of these instruments, other cheaper and moreaccessible types of methods have already been recommended to evaluate this problem in elderly people, among which stands out the anthropometry used for the estimation of muscle mass, especially for epidemiological purposes [9,11-13]. This method allows the use of anthropometric measurements in valid predictive equations for estimating the amount of muscle mass and the prevalence of sarcopenia, and ithasalso been tested in a study with the Brazilian elderly [12].

Given the above, studies focusing on the prevalence of sarcopenia are relevant because they are useful in developing and guiding public health programs, policies that will guide the population in general beforehand and mainly make the elderly adopt habits that reduce risks of developing sarcopenia. Furthermore, these studies foster the investigation to find which subgroups of elderly people may be more susceptible to the development of this outcome, thus facilitating the implementation of emergency strategies for sarcopenia care. In this sense, this study aims to determine the prevalence of sarcopenia and its association with demographic and nutritional status in the elderly of a capital of southern Brazil.

\section{Methods}

This study was conducted in the urban area of the Florianópolis city, capital of Santa Catarina state, Brazil. The municipality had apopulation of 421,240 inhabitants in 2010, distributed in a land area of $908.02 \mathrm{~km} 2$. Florianópolis has, on its natural scenery, beaches, rocky shores, salt marshes, mangroves and dunes. The morphology is discontinuous, formed by crystal mountains coming up to 532 meters of altitude. The municipal human development index (HDI-M) was 0.847 in 2010, considered high, placing the city in the $3 \mathrm{rd}$ positionamong all Brazilian capitals. The life expectancy was 77.4 years, higher than the ones referring to Santa Catarina State (76.6years) and Brazil (73.9years). In 2010, it presented a total fecundity rate (children per woman) of 1.2 children, urbanization rate of $96.2 \%$, dependency ratio of $34.1 \%$, and aging rate of $7.5 \%$. The average per capita income of Florianópolis has grown by $95 \%$ in thelast two decades [14] The poverty ratewas $23.5 \%$ and the Gini indexwas 0.40 [15]. The city had a population of 48,000 elderly: 20,529 men and 27,894 women [15].

This epidemiological study with cross-sectional design was conducted with elderly participants of the following physical activity projects: Third Age Study Group at UDESC, Santa Catarina State University; and Physical and Aquatic Activities for the Third Age of UFSC, Federal University of Santa Catarina. The sample of this research was intentionally selected with the following inclusion criteria: elderly people ( $>60$ years), individuals who participated in physical activity projects in 2010 and that were present on the day scheduled for data collection.

The data collection took place at the premises of the Center for Health and Sport Sciences at UDESC and at the Sports Center in UFSC. Prior to collection, the elderly were informed about the study and those interested in participating signed an Informed Consent Form. The entire team of data collection, consisting of academics and physical education teachers, has been previously trained.

There were collected anthropometric measurements of body mass and height, according to Brazilian standardization [16]. The measurement of body mass was accomplished by means of a digital scale Plenna Wind MEA 07710, with a resolution of 100 grams and capacity of $150 \mathrm{~kg}$. The height wasmeasured using a portablestadiometer fromWCSbrand, $217 \mathrm{~cm}$, with Cardiomed brand platform, with a resolution of $1 \mathrm{~mm}$. Subsequently, concerning the collected data, we 
calculated the body mass index (BMI $=\mathrm{kg} / \mathrm{m} 2)$. The weight status was classified according to previous recommendations: $\mathrm{BMI}<22.0 \mathrm{~kg} / \mathrm{m} 2$ - underweight, $22.0 \leq \mathrm{BMI} \leq 27.0 \mathrm{~kg} / \mathrm{m} 2-$ normal weight and BMI $>27.0 \mathrm{~kg} / \mathrm{m} 2$ - obesity [17].

The estimation of muscle mass (MM) was performed using the equation of Lee et al. [18] validated for use with elderly Brazilians (13): Muscular Mass (kg) $=(0.244$ *body mass $)+(7.80 *$ height $)+(0.098 *$ age $)+(6.6 *$ gender $)+$ (ethnicity-3.3). The variables were represented according to the following values: 1 for men and 0 for women; ethnicity = -1.2 for Asian, 1.4 for African descent and 0 for Caucasians. After the estimation of muscle mass, the muscular mass index (MMI) was calculated: $\mathrm{MMI}\left(\mathrm{kg} / \mathrm{m}^{2}\right)$ = Muscular Mass (kg) / (Height) ${ }^{2}$ (m) [19].

After the calculation, we found the prevalence of sarcopenia according to Janssen et al. [19]. Sarcopenia can be divided into three categories (normal, moderate and severe). Owing to the low number of elderly people with severe sarcopenia, the categories "moderate" and "severe" were grouped, denominating them as presence of sarcopenia. The variable "age" was categorized into four groups according to age groups (60-64, 65-69, 70-74, and $\geq 75)$.

A descriptive analysis of the variables studied (mean, standard deviation and frequency distribution) was performed. The normality of the data was tested using the Kolmogorov-Smirnov test, accepting $\mathrm{p}$ values $>0.05$. An indicative case of non-normal distribution, the $\mathrm{U}$ Mann-Whitney test was used for comparison of data. The Chi-square and Fisher's Exact tests were used to assess the association between the presence/absence of sarcopenia and gender (male, female), age (60-64, 65$69,70-74$, and $\geq 75$ ) and BMI (eutrophic, underweight and obesity). The comparison of the MMI between age groups was verified by two-way ANOVA with post hoc of Bonferroni. The logistic regression analysis, gross and adjusted, was used to verify the association of the outcome (sarcopenia) with the independent variables (gender, age group and nutritional status), presenting the values of the Odds Ratio (OR) with the respective confidence intervals of $95 \%$ (95\% IC). For the adjusted logistic regression analysis, all variables were included in the model, regardless of the value of $\mathrm{p}$ in the crude analysis. In all analyses, the adopted significance level was $5 \%(\mathrm{p}<0.05$ or $95 \%)$.

The project was approved by the Ethics Committee on Research with Human Beings of the Santa Catarina State University, according to ruling n. 02/2010.

\section{Results}

Table 1 shows the sample general characteristics of the elderly sample. The average age of participants was 79.9 (standard deviation $=6.0$ ) years, and $369(84.2 \%)$ were women. We verified a significant higher average for male body mass, height, muscle mass, and muscle mass index. On the other hand, statistically higher values were observed among women in the body mass index. The prevalence of sarcopenia among elderly was 33.3\% (moderate + severe), with higher rates in males.

Table $\mathbf{1}$ - General characteristics of the sample of elderly

\begin{tabular}{|c|c|c|c|c|}
\hline \multirow[t]{2}{*}{ Variables } & $\begin{array}{l}\text { Total }(\mathrm{n} \\
=438)\end{array}$ & $\begin{array}{l}\text { Male }(\mathrm{n} \\
=69)\end{array}$ & $\begin{array}{c}\text { Female }(\mathrm{n} \\
=369)\end{array}$ & \multirow[t]{2}{*}{$p$-value } \\
\hline & $\bar{x}(\mathrm{sd})$ & $\bar{x}(s d)$ & $\bar{x}(\mathrm{sd})$ & \\
\hline Age (years) & $\begin{array}{l}79.9 \\
(6.0)\end{array}$ & $\begin{array}{l}71.5 \\
(6.4)\end{array}$ & $70.8(6.0)$ & 0.393 \\
\hline $\begin{array}{l}\text { Body Mass } \\
(\mathrm{kg})\end{array}$ & $\begin{array}{l}68.1 \\
(11.3)\end{array}$ & $\begin{array}{l}74.3 \\
(10.9)\end{array}$ & $\begin{array}{l}67.0 \\
(11.0)\end{array}$ & $<0.001$ \\
\hline Height (m) & $1.6(0.1)$ & $1.7(0.1)$ & $1.5(0.1)$ & $<0.001$ \\
\hline BMI $\left(\mathrm{kg} / \mathrm{m}^{2}\right)$ & $\begin{array}{l}27.9 \\
(4.3)\end{array}$ & $\begin{array}{l}26.5 \\
(3.5)\end{array}$ & $28.1(4.4)$ & 0.002 \\
\hline MM (kg) & $\begin{array}{l}20.2 \\
(4.9)\end{array}$ & $\begin{array}{l}27.4 \\
(3.2)\end{array}$ & $18.8(3.9)$ & $<0.001$ \\
\hline MMI (kg) & $8.2(1.6)$ & $9.8(0.9)$ & $7.9(1.5)$ & $<0.001$ \\
\hline $\begin{array}{l}\text { Age Group } \\
\text { (years) }\end{array}$ & n (\%) & n (\%) & n (\%) & 0.819 \\
\hline $60-64$ & $72(16.5)$ & $\begin{array}{l}11 \\
(15.9)\end{array}$ & 61 (16.5) & \\
\hline $65-69$ & $\begin{array}{l}125 \\
(28.5)\end{array}$ & $\begin{array}{l}17 \\
(24.6)\end{array}$ & $108(29.3)$ & \\
\hline $70-74$ & $\begin{array}{l}113 \\
(25.8)\end{array}$ & $\begin{array}{l}18 \\
(26.2)\end{array}$ & 95 (25.7) & \\
\hline$\geq 75$ & $\begin{array}{l}128 \\
(29.2)\end{array}$ & $\begin{array}{l}23 \\
(33.3)\end{array}$ & $105(28.5)$ & \\
\hline Weight Status & & & & 0.001 \\
\hline Eutrophic & $\begin{array}{l}236 \\
(53.9)\end{array}$ & $\begin{array}{l}42 \\
(60.9)\end{array}$ & $138(37.4)$ & \\
\hline Underweight & $22(5.0)$ & $04(5.8)$ & $18(4.9)$ & \\
\hline Obesity & $\begin{array}{l}180 \\
(41.1)\end{array}$ & $\begin{array}{l}23 \\
(33.3)\end{array}$ & $213(57.7)$ & \\
\hline Sarcopenia & & & & $<0.001$ \\
\hline Normal & $\begin{array}{l}292 \\
(66.7)\end{array}$ & $\begin{array}{l}10 \\
(14.5)\end{array}$ & $282(76.5)$ & \\
\hline Moderate & $\begin{array}{l}133 \\
(30.3)\end{array}$ & $\begin{array}{l}55 \\
(79.7)\end{array}$ & 78 (21.1) & \\
\hline Severe & $13(3.0)$ & $04(5.8)$ & $09(2.4)$ & \\
\hline
\end{tabular}

Note: $\mathrm{x}=$ mean; $\mathrm{sd}=$ standard deviation; $\mathrm{BMI}=$ body mass index MM = skeletal muscle mass; $M M I=$ muscle mass index; $p$-value $=$ difference between gender's in mean values or proportions. 
Table 2 shows the characteristics of elderly in accordance with the absence and presence of sarcopenia. The results indicate a higher proportion of sarcopenia among elderly males, individuals aged above 75 years, and those with low weight.

Table 2 - Elderly characteristics according to the absence or presence of sarcopenia

\begin{tabular}{|c|c|c|c|}
\hline \multirow{3}{*}{ Variables } & \multicolumn{2}{|c|}{ Sarcopenia } & \multirow{3}{*}{$\mathrm{p}$-value } \\
\hline & Absence & $\begin{array}{c}\text { Moderate/ } \\
\text { Severe }\end{array}$ & \\
\hline & n (\%) & n (\%) & \\
\hline Gender & & & $<0.001$ \\
\hline Male & $10(14.5)$ & $59(85.5)$ & \\
\hline Female & $282(76.4)$ & 87 (23.6) & \\
\hline Age Group (years) & & & 0.001 \\
\hline $60-64$ & $54(75.0)$ & $18(25.0)$ & \\
\hline $65-69$ & 93 (74.4) & $32(25.6)$ & \\
\hline $70-74$ & $74(65.5)$ & $39(34.5)$ & \\
\hline$\geq 75$ & $71(55.5)$ & 57 (44.5) & \\
\hline Weight Status † & & & $<0.001$ \\
\hline Eutrophic & $68(37.8)$ & 112 (62.2) & \\
\hline Underweight & 03 (13.6) & $19(86.4)$ & \\
\hline Obesity & $221(93.6)$ & $15(6.4)$ & \\
\hline
\end{tabular}

Note: $\uparrow$ Fisher’s Exact.

Figure 1 shows the values of the MMI of elderly according to age group, stratified by gender. In men, there was no significant difference in the mean values of MMI between age groups. On the other hand, there was a trend in average MMI in women inversely proportional to age $(p<0.05)$, i.e., elderly females aged $\geq 75$ years showed statistically lower values when compared to other age groups (60-64, 65-69 and 70-74 years).

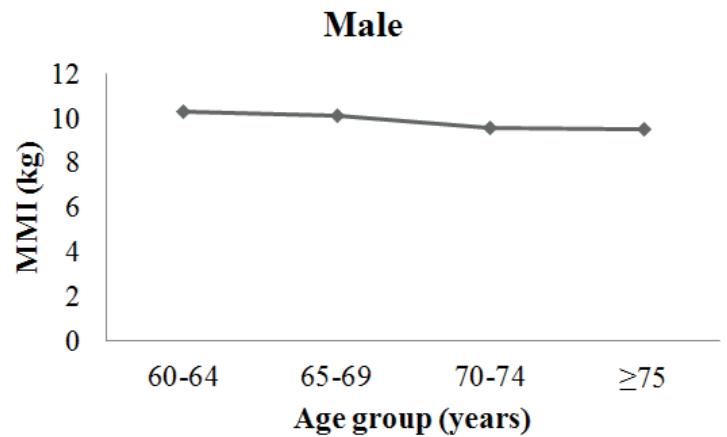

The results of the crude analysis revealed that all independent variables were associated with the outcome. When the analysis was adjusted, it was observed that the male gender (OR: 196.33, 95\% CI = 40.05-962.54), the age group "75 years or more" (OR: $3.73,95 \% \mathrm{CI}=1.41-9.91$ ) and low-weight individuals (OR: $5.79,95 \% \mathrm{CI}=1.52-21.40$ ) were associated with moderate/severe sarcopenia. Obese elderly had less chances of sarcopenia than elderly with normal weight (OR: 0.01, 95\% CI =0.00-0.03) (Table 3).

Table 3 - Association between sarcopenia, demographic variables (gender, group age) and nutritional state in elderly

\begin{tabular}{|c|c|c|c|c|}
\hline Variables & $\begin{array}{c}\text { OR } \\
(95 \% \mathrm{Cl})\end{array}$ & $\mathrm{p}$-value & $\begin{array}{c}\mathrm{OR}^{\star *} \\
(95 \% \mathrm{Cl})\end{array}$ & $p$-value \\
\hline \multicolumn{5}{|l|}{ Gender } \\
\hline Female & 1 & & 1 & \\
\hline Male & $\begin{array}{l}19.12 \\
(9.38- \\
38.98)\end{array}$ & $<0.001$ & $\begin{array}{l}196.33 \\
(40.05- \\
962.54)\end{array}$ & $<0.001$ \\
\hline \multicolumn{5}{|l|}{ Age (years) } \\
\hline $60-64$ & 1 & & 1 & \\
\hline $65-69$ & $\begin{array}{l}1.03 \\
(0.53- \\
2.01)\end{array}$ & 0.926 & $\begin{array}{l}1.36 \\
(0.52- \\
3.57)\end{array}$ & 0.535 \\
\hline $70-74$ & $\begin{array}{l}1.58 \\
(0.82- \\
3.06)\end{array}$ & 0.173 & $\begin{array}{l}2.45 \\
(0.90- \\
6.64)\end{array}$ & 0.078 \\
\hline$\geq 75$ & $\begin{array}{l}2.41 \\
(1.27- \\
4.56)\end{array}$ & 0.007 & $\begin{array}{l}3.73 \\
(1.41- \\
9.91)\end{array}$ & 0.008 \\
\hline \multicolumn{5}{|c|}{ Weight Status } \\
\hline Eutrophic & 1 & & 1 & \\
\hline Underweight & $\begin{array}{l}3.85 \\
(1.10- \\
13.38)\end{array}$ & 0.035 & $\begin{array}{l}5.79 \\
(1.52- \\
21.40)\end{array}$ & 0.010 \\
\hline Obesity & $\begin{array}{l}0.04 \\
(0.02- \\
0.08)\end{array}$ & $<0.001$ & $\begin{array}{l}0.01 \\
(0.00- \\
0.03)\end{array}$ & $<0.001$ \\
\hline
\end{tabular}

Note: $\mathrm{OR}=$ Odds Ratio; $95 \% \mathrm{Cl}=$ confidence interval; ** Analysis adjusted for all independent variables.

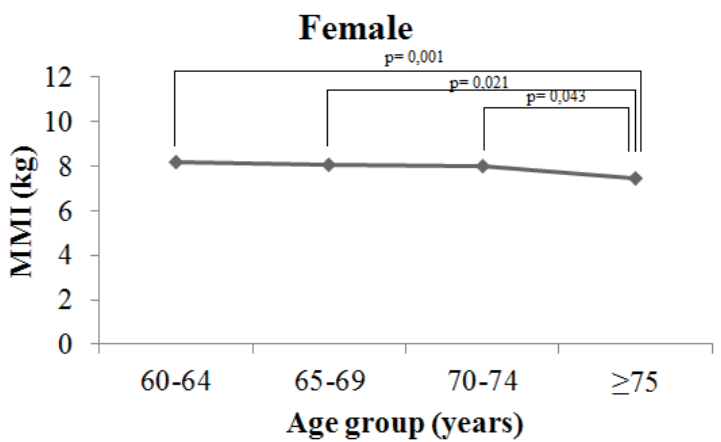

Figure $\mathbf{1}$ - Muscle mass index of elderly according to age group, stratified by gender. 


\section{Discussion}

Among the main findings, it is emphasized that approximately one third of the investigated elderly people has moderate/severe sarcopenia, even when participating in physical activity programs. Furthermore, the MMI tended to decrease with increasing age.

The prevalence of sarcopenia was $33.3 \%$. Similar prevalence was reported in other studies conducted in adults and elderly Thai (35.0\%) [20] and Mexican individuals (36.6\%) [21]. On the other hand, the lower prevalence of sarcopenia was observed in Chinese (11.4\%) [22] and Thai elderly people (9.6\%) [23]. In Brazil, the prevalence of sarcopenia to date was lower than what we found in this study. For example, in São Paulo, $16.1 \%$ of women and $14.4 \%$ of men were diagnosed with sarcopenia [24]. Recently, Dutra et al. observed women aged 60 years or older living in the urban zone of the municipality of Lafaiete Coutinho, Bahia, Brazil, and verified that $17.8 \%$ had sarcopenia [10]. The differences between these studies should be analyzed with caution, mainly owing to the use of different methods applied for the evaluation and classification of sarcopenia (DEXA, anthropometry, bioelectrical impedance). Thus, it is not impossible that the prevalence found in this study was overestimated, considering that our sample was convenient, which unfortunately undermines our results.

It is possible to observe in this study a tendency of reducing MMI with the increase of age, especially in females. Studies indicate that the loss of muscle mass is associated with age $[6,22,25]$, which seems to be natural, since the aging process provides reduction of muscle mass of 3 to $8 \%$ per decade, especially if the elderly do not practice regularly physical activities [5]. These findings are disturbing because the reduction of muscle mass has a direct impact on the functional capacity of the elderly and may adversely impact their lives $[6,26]$. In this context, the estimation of muscle mass seems to be a good indicator of body composition that can be used in programs of exercise and nutrition, supporting the diagnosis of risks in order to enable appropriate interventions, and improving the quality of life for seniors.

The elderly aged 75 years or more were more likely to have sarcopenia. These results confirm the evidence found by Yamada et al., who found that the prevalence of sarcopenia in elderly Japanese increased from 8.6\% in those aged less than 70 years to $39.6 \%$ in those aged
80 years or older [27]. Dutra et al. also showed that the strongest associations with sarcopenia were with ages over 80 years [10]. The etiology of sarcopenia is multifactorial and its progression is usually attributed to age-related changes in skeletal muscle and the interaction of numerous factors, which may explain the results of this study. Among these factors related to the increase of age, stand out the decrease in hormone secretion, insulin resistance, decreased insulin growth factor, and increased inflammatory cytokines [28].

Regarding the association between sarcopenia and weight status (BMI), we observed an inverse association, in which the obese elderly were less likely to have sarcopenia than those eutrophic. These results differ from the findings of Baumgartner etal. [29], who investigated the association of sarcopenic obesity with the onset of disability in daily living instrumental activities during a follow-up of eight years. They found that obese sarcopenic are two to three times more likely to develop this inability than individuals only sarcopenic or non-sarcopenic obese. Thus, in general, obese people have a greater chance of developing sarcopenia than non-obese individuals [4].

On the other hand, it was observed that individuals with low weight were more likely to have sarcopenia when compared to their eutrophic pairs. These results corroborate the findings of the elderly of the United Kingdom [30] and Italia [11], which shows that the low weight is associated with increased sarcopenia. Probably, this is owing to the low intake of nutrients and the energy shortage affecting undernourished people, harming the body composition [30].

The present study has limitations concerning the cross-sectional design, which cannot verify reverse causalities between variables, the body composition analysis by doubly indirect method (anthropometry), and intentional sample selection.

\section{Conclusion}

The results demonstrate that the prevalence of sarcopenia is greater than $30 \%$ and it increases with age. The population subgroups with higher chances of sarcopenia were: males, individuals with age 75 or older, and those with low weight. These findings contribute to a better understanding of sarcopenia, which can help to take policy actions of health promotion as an incentive to practice regular physical activities and concomitantly have healthy eating habits. 


\section{References}

1. Instituto Brasileiro de Geografia e Estatística- IBGE. Mudanças Demográficas no Brasil no Início do Século XXI: Subsídios para as Projeções da População [cited 2017 May 15]. Available from: https://tinyurl.com/ y9uaecqz.

2. Sun F, Norman IJ, While AE. Physical activity in older people: a systematic review. BMC Public Health. 2013;13:449.

3. Hairi NN, Cumming RG, Naganathan V, Handelsman DJ, Le Couteur DG, Creasey H, et al. Loss of muscle strength, mass (sarcopenia), and quality (specific force) and its relationship with functional limitation and physical disability: the Concord Health and Ageing in Men Project. J Am Geriatr Soc. 2010;58(11):2055-62.

4. Kalinkovich A, Livshits G. Sarcopenic obesity or obese sarcopenia: A cross talk between age-associated adipose tissue and skeletal muscle inflammation as a main mechanism of the pathogenesis. Ageing Res Rev. 2017;35:200-21.

5. WestcottWL. Resistancetrainingismedicine: effects of strength training on health. Curr Sports Med Rep. 2012;11(4):209-16.

6. Kim YS, Lee Y, Chung YS, Lee DJ, Joo NS, Hong D, et al. Prevalence of sarcopenia and sarcopenic obesity in the Korean population based on the Fourth Korean National Health and Nutritional Examination Surveys. J Gerontol A Biol Sci Med Sci. 2012;67(10):1107-13.

7. Silva TAA, Frisoli Jr A, Pinheiro MM, Szejnfeld VL. Sarcopenia and aging: aspects and therapeutic options. Rev Bras Reumatol. 2006;46(6):391-7.

8. Diz JBM, Queiroz BZ, Tavares LB, Pereira LSM. Prevalence of sarcopenia among the elderly: findings from broad cross-sectional studies in a range of countries. Rev Bras Geriatr Gerontol. 2015;18(3):665-78.

9. Li Z, Heber D. Sarcopenic obesity in the elderly and strategies for weight management. Nutr Rev. 2012;70(1):57-64.

10. Dutra T, Pinheiro PA, Carneiro JAO, Coqueiro RS, Fernandes MH. Prevalence and factors associated with sarcopenia in elderly women living in the community. Rev Bras Cineantropom Desempenho Hum. 2015;17(4):460-71.
11. Landi F, Liperoti R, Fusco D, MastropaoloS, Quattrociocchi D, Proia A, et al. Prevalence and risk factors of sarcopenia among nursing home older residents. J Gerontol A Biol Sci Med Sci. 2012;67(1):48-55.

12. Silva Neto LS, Karnikowiski MG, Tavares AB Lima RM. Association between sarcopenia, sarcopenic obesity, muscle strength and quality of life variables in elderly women. Rev Bras Fisioter. 2012;16(5):360-7.

13. Rech CR, Dellagrana RA, Marucci MFN, Petroski EL. Validity of anthropometric equations for the estimation of muscle mass in the elderly. Rev Bras Cineantropom Desempenho Hum. 2012;14(1):23-31.

14. Programa das Nações Unidas para o DesenvolvimentoPNUD: Valores e Desenvolvimento Humano. 2013 [cited 2017 Apr7]. Available from: https://tinyurl.com/y7qpdq5h.

15. Instituto Brasileiro de Geografia e Estatística- IBGE. Síntese de indicadores sociais: uma análise das condições de vida da população brasileira [cited 2017 Apr 7]. Available from: https://tinyurl.com/y78juwnw.

16. Alvarez BR, Pavan AL. Alturas e comprimentos. In: Petroski EL. Antropometria: técnicas e padronizações. Porto Alegre: Palotti; 1999. p. 29-51.

17. American Academy of Family Physicians, American Dietetic Association, National Council on the Aging. Nutrition screening e intervention resources for healthcare professionals working with older adults. Nutrition Screening Initiative. Washington: American Dietetic Association; 2002 [cited 2017 Mar 16]. Available from: https://tinyurl.com/ycysrf4w.

18. Lee RC, Wang Z, Heo M, Ross R, Janssen I, Heymsfield SB. Total-body skeletal muscle mass: development and cross-validation of anthropometric prediction models. Am J Clin Nutr. 2000;72(3):796-803.

19. Janssen I, Baumgartner RN, Ross R, Rosenberg IH, Roubenoff R. Skeletal muscle cut points associated with elevated physical disability risk in older men and women. Am J Epidemiol. 2004;159(4):413-21.

20. Pongchaiyakul C, Limpawattana P, Kotruchin P, Rajatanavin R. Prevalence of sarcopenia and associated factors among Thai population. J Bone Miner Metab. 2013;31(3):346-50.

21. Arango-Lopera VE, Arroyo P, Gutiérrez-Robledo LM, Perez-Zepeda MU. Prevalence of sarcopenia in Mexico City. Eur Geriatr Med. 2012;3(3):157-60. 
22. Cheng Q Zhu X, Zhang X, Li H, Du Y, Hong W, et al. A crosssectional study of loss of muscle mass corresponding to sarcopenia in healthy Chinese men and women: reference values, prevalence, and association with bone mass. J Bone Miner Metab. 2014;32(1):78-88.

23. Liu LK, Lee WJ, Chen LY, Hwang AC, Lin MH, Peng LN, et al. Sarcopenia, and its association with cardiometabolic and functional characteristics in Taiwan: results from I-Lan Longitudinal Aging Study. Geriatr Gerontol Int. 2014;14(Suppl 1):36-45.

24. Alexandre TS, Duarte YA, Santos JL, Wong R, Lebrão ML. Prevalence and associated factors of sarcopenia among elderly in Brazil: findings from the SABE study. J Nutr Health Aging. 2014;18(3):284-90.

25. Wu IC, Lin CC, Hsiung CA, Wang CY, Wu CH, Chan DC, et al. Epidemiology of sarcopenia among community-dwelling older adults in Taiwan: a pooled analysis for a broader adoption of sarcopenia assessments. Geriatr Gerontol Int. 2014;14(Suppl 1):52-60.

26. Kim JK, Choi SR, Choi MJ, Kim SG, Lee YK, Noh JW, et al. Prevalence of and factors associated with sarcopenia in elderly patients with end-stage renal disease. Clin Nutr. 2014;33(1):64-8.
27. Yamada M, Nishiguchi S, Fukutani N, Tanigawa T, Yukutake T, Kayama H, et al. Prevalence of sarcopenia in community-dwelling Japanese older adults. J Am Med Dir Assoc. 2013;14(12):911-5.

28. Narici MV, Maffulli N. Sarcopenia: characteristics, mechanisms and functional significance. Br Med Bull. 2010;95(1):139-59.

29. Baumgartner RN, Wayne SJ, Waters DL, Janssen I, Gallagher D, Morley JE. Sarcopenic obesity predicts instrumental activities of daily living disability in the elderly. Obes Res. 2004;12(12):1995-2004.

30. Patel HP, Syddall HE, Jameson K, Robinson S, Denison $\mathrm{H}$, Roberts HC, et al. Prevalence of sarcopenia in community-dwelling older people in the UK using the European Working Group on Sarcopenia in Older People (EWGSOP) definition: findings from the Hertfordshire Cohort Study (HCS). Age and Ageing. 2013;42(3):378-84.

Received in 11/05/2017 Recebido em 05/11/2017 Recibido en 05/11/2017

Approved in 02/16/2018 Aprovado em 16/02/2018 Aprobado en 16/02/2018 